\title{
Water resource distribution and tectonics in the tulum valley, Western Central Argentina
}

\begin{abstract}
A gravimetric analyse over the Tulum Valley was made. This data was used to reveal the tectonic structures in the Valley. Gravity data was processed using upward continuation and vertical derivative filters and all the results were compared with drainage systems and groundwater maps of the area. Both groundwater and surfacewater are highly demanded resources due to their scarcity. The drainage network and groundwater are influenced by tectonic structures in the Tulum valley. In the piedmont of the Sierra Chica de Zonda the broom-shaped river pattern correspond to Quaternary faults. While in the central Tulum Valley, the depocenter basin is a water recipient, the groundwater table permanently close to the surface and they are considered discharge. The depocenter is linked to paleo-swamps and wetlands in a past wetter environment. In the Tulum fault systems area, streams adapt its drainage network bordering basements blocks uplifts. In turn, the blocks uplift behaves as a hydrogeological barrier for the groundwater basin. Also, in the alluvial fan of San Juan River the free aquifer is affected by a Tertiary uplift block. From this study, it was concluded that tectonic structures control surface and groundwater resources in the Tulum Valley.
\end{abstract}

Keywords: surface water, ground water, gravimetric data, tectonic
Volume 2 Issue I - 2018

\author{
Aixa Inés Rodríguez,' Patricia Martinez,' \\ Graciela Mabel Suvires ${ }^{2}$ \\ 'CONICET, National University of San Juan, Volponi Geophysical \\ \& Seismological Institute, Argentina \\ ${ }^{2}$ CONICET-CIGEOBIO, National University of San Juan, \\ Argentina
}

\begin{abstract}
Correspondence: Aixa Inés Rodríguez, CONICET-National University of San Juan, Volponi Geophysical \& Seismological Institute, San Juan, Argentina, Email aixabosco@hotmail.com, aixarodriguez@conicet.gov.ar
\end{abstract}

Received: January 15, 2018| Published: February 07, 2018

\section{Introduction}

Tulum Valley extends over a broken foreland basin comprised between the geological province Precordillera Oriental ${ }^{1}$ to the west, and the Sierras Pampeanas Occidentales to the east, on the active deformation front of the Central Andes which, in turn, features a dominant compressive system associated to the NazcaSouth American plates drift system (Figure 1). The main structural configuration of the basin is explained by the planar geometry of the Nazca plate subducting under the South American plate. ${ }^{2-6}$ Tulum Valley is located in central-western Argentina, in a particularly arid region of the Province of San Juan. The population of this valley, where the province's capital city of San Juan lies, is 629.530 inhabitants. ${ }^{7}$ The climate is arid to desertic (Bwk, Koeppen) where daily and seasonal temperatures vary greatly. The annual mean temperature ranges from $14^{\circ} \mathrm{C}$ to $19^{\circ} \mathrm{C}$. The annual rainfall values range within $100-124 \mathrm{~mm}$. The basin is filled by Quaternary sediment and Tertiary sedimentites. Extensive geoforms are developed, such as the alluvial fan of San Juan river that holds an underground water basin extending over $3700 \mathrm{~km}^{2}{ }^{8,9}$ Tectonic action is the predominant source for the formation of geological features of this valley and its fault system of Quaternary activity. This system represents most of the active deformation known up to date in Argentina ${ }^{10}$ Tulum Valley shows significant faulting, such as the Tulum Fault System ${ }^{11}$ that intersects the valley with a NNE-SSW trending. These are thrust faults, almost vertical, bordering the uplift blocks of the broken foreland basin, which give rise to flexural basins. ${ }^{12}$ The present study was made on three sectors in the Tulum Valley. The first zone related to an area of greater richness of groundwater, in the middle sector of the alluvial fan of the San Juan River, in the underground free aquifer. The second zone corresponds to the depocenter of the basin, which receives all the contributions of both groundwater and surface-water. The zone is linked to paleo-swamps and organics soils in the past wetter environment. The third zone is the Tulum fault system. A map of residual gravimetric anomalies using an upward continuation filter and enhancement through first vertical derivate is presented. Tectonic environments and main tectonic structures were delimited in the map. These are associated with the distribution of water resources in this desert region, with the highest population density in the San Juan province. Both groundwater and surface-water are highly demanded resources due to their scarcity. This panorama worsens through time due to a marked population growth and its associated rise in social and economic development (Figure 1).
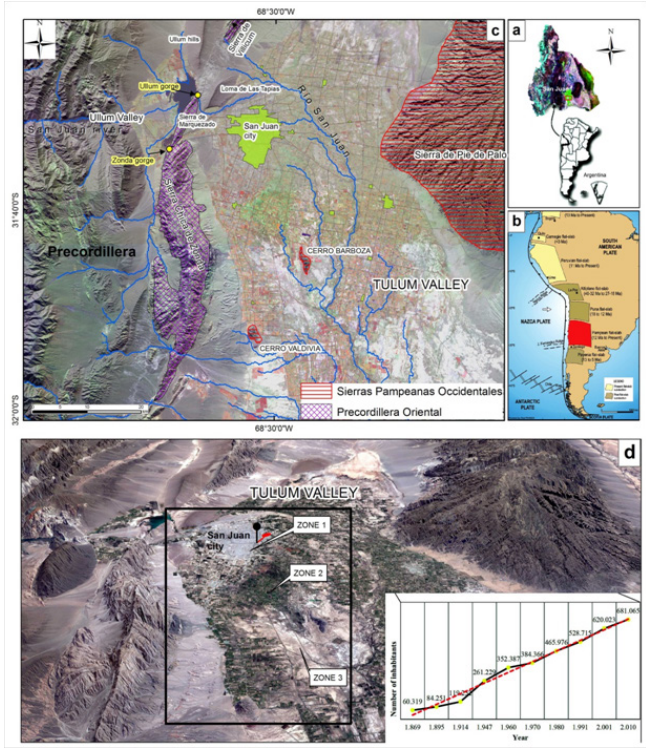

Figure I a, Location of Tulum Valley, Province of San Juan, central-west Argentina; b, Location of Tulum Valley Basin, red-shaded area in the Pampean flat slab sector; c, The Tulum Valley is between two geological provinces, Precordillera Oriental and Sierras Pampeanas Occidentales; d, Studied area, black-rimmed square (Google Earth 2017 image), three zones of interest are highlighted, The chart shows a rapid population growth for the Tulum valley. 


\section{Materials and methods}

Gravity data was provided by the Instituto Geofísico Sismológico Volponi (IGSV). Bouguer anomaly maps were obtained applying statistical gridding techniques (Kriging) using Oasis Montaj ${ }^{\circledR}$ software. The Bouguer anomaly map contains two effects; one regional (attributed to the lower crust and mantle) and another residual (attributed to upper crust and intrabasement gravity sources). The regional-residual separation was obtained using upward continuation filters to a height of $10 \mathrm{~km}$. The residual anomaly was enhanced by means of the vertical derivate method, a resource that enhances the density contrasts appearing near the surface, by amplifying the highfrequency component of the spectrum. A geomorphologic analysis was made by interpreting satellite imagery on GIS references. Digital elevation models were used to the drainage network, with a $12.5 \mathrm{~m}$ and $5 \mathrm{~m}$ resolution: ALOS-1 Palsar DEM \& IGN..$^{13,14}$ Furthermore, in order to know the geographic distribution of paleo-swamps and wetlands an historical analysis and field work were made.

\section{Results}

\section{Gravimetric analysis}

A residual anomalies map obtained by Upward Continuation which was subject to a process of anomalies enhancement through first order vertical derivative method (Figure 2). In the map cold tones representing lower gravimetric readings and high gravimetric anomalies indicated by reddish-rosy shades. The Figure 2 show:

a. A positive gravimetric anomaly located under the alluvial fan of San Juan River. This gravimetric high is associated to a structural high born in the Tertiary, which generates, toward the $\mathrm{E}$ and $\mathrm{W}$, two tectonically depressed sectors.

b. Low gravity values are noted in the sector corresponding to the basin depocenter: It has an approximately elongated shape extending N-S.

c. On the SE sector of the map gravimetric high anomaly appears. There lies the Tulum fault system which delimits, through thrust faults, uplifts blocks of a broken foreland basin. The Tulum Fault System intersects the valley with a NNE-SSW trending. These are thrust faults, almost vertical, bordering the uplift blocks of the broken foreland basin.

\section{Surface and groundwater resources}

Superficial water resources: Drainage network is shown in the Figure 3. The draining system is featured mainly by the San Juan River and smaller streams. San Juan river has its headwaters in the highlands of the Central Andes, drains major morpho-structural units of geological provinces of Central Andes and Its general course flows from west to east, crossing the Precordillera range and continues further eastwards across tectonic depressions. ${ }^{15}$ Both Agua Negra and Los Tapones streams have their headwaters in the central part of the Tulum Valley. The headwaters are not connected with the Andes range or Eastern Precordillera. The drainage system along the study region can be subdivided into major areas (named A, B, C, D, E, F \& G) with different drainage network patterns (Figure 3):

a. Alluvial fan of the San Juan River. The network is radial and dichotomic, according to the geoform. To the north of San Juan River there is a watershed divide. The line separates the drainage to the North (base level El Jumeal) and to the south (base level Lagunas de Guanacache).

b. Sierra Chica de Zonda: as a trellis pattern. The main stream flows along a strike valley and smaller tributaries feed into it from the steep slopes on the sides of mountains. These tributaries enter the main river at right angles, causing a trellis-like appearance of the river system. The streams follow the directions of folding and fractures with direction W-E. In addition, in this area the streams are ephemeral water courses.

c. Piedmont of Sierra Chica de Zonda: the streams emerging from the Sierra Chica de Zonda front branch to the east into multiple channels delineating the active alluvial fans. Main flow direction is W-E. There are several types of drainage pattern. These patterns include Dichotomic, radial, divergent pattern (indicated with a yellow circle) and broom-shaped river pattern (indicated with a red circle).

d. The streams cut relatively straight across zone $\mathrm{D}$, to the north and south of Valdivia and Barboza hills respectively. Streams converge just in the Paleo-wetland "Ciénaga Grande". Main flow direction is W-E and NW-E. Streams tend to stretch out in a parallel like fashion following the slope of the surface.

e. Geographic distribution of paleo-swamps and wetlands in the Tulum valley, according to historical analysis and field work. The paleo-swamp "Ciénaga Grande" was a receiving medium of groundwater and surface-water. Other swamps were located in the headwaters of both Agua Negra and Los Tapones streams. Points indicate areas with possible presence of paleo swamps or wetlands, but its confirmation requires further studies.

f. Streams adapt its drainage network bordering Cerros Valdivia y Barboza, and the pattern is repeated in the sectors indicated with F. According to Rodríguez et al16 the streams and San Juan River fits drainage network bordering basements blocks uplifts of the Tulum fault system.

g. San Juan River and streams are deflected southward. Main direction is NNW-SSE and N-S. The ephemeral streams seem to dead-end in sand dunes.

\section{Groundwater resources}

Hydrogeological studies ${ }^{8,17-20}$ show the extension of a large underground water basin in Tulum Valley. This, in turn is divided into sub-basins separated by hydrogeological barriers (faults, uplift tectonic blocks and synclinal structures). The sub-basins are Upper Tulum (A), Lower Tulum (B), Loma de Las Tapias and Villicum subbasins (Figure 4). The main recharge source of the basin is the San Juan River. The formations regarded non-aquiferous, which delimit the basin and constitute its base, are of Pre-Cambrian, Paleozoic and Tertiary ages, whereas the alluvial fill, which holds underground water, originated in the Quaternary. ${ }^{19}$ An alluvial fan was formed during the late Pleistocene in the Tulum Valley. The extensive alluvial fan of the San Juan River holds coarse deposits, mainly gravel, sands and interspaced lenticular lime and sand deposits. In the alluvial fan there is a single aquifer that behaves as a free aquifer. Going eastward, and due to the presence of impermeable or semi-impermeable layers, this aquifer is split into two by confined and semi-confined aquifers, denominated as upper and lower aquifers. ${ }^{8,19}$ The groundwater flow direction in the alluvial fan is predominantly SE..$^{19,21}$ 


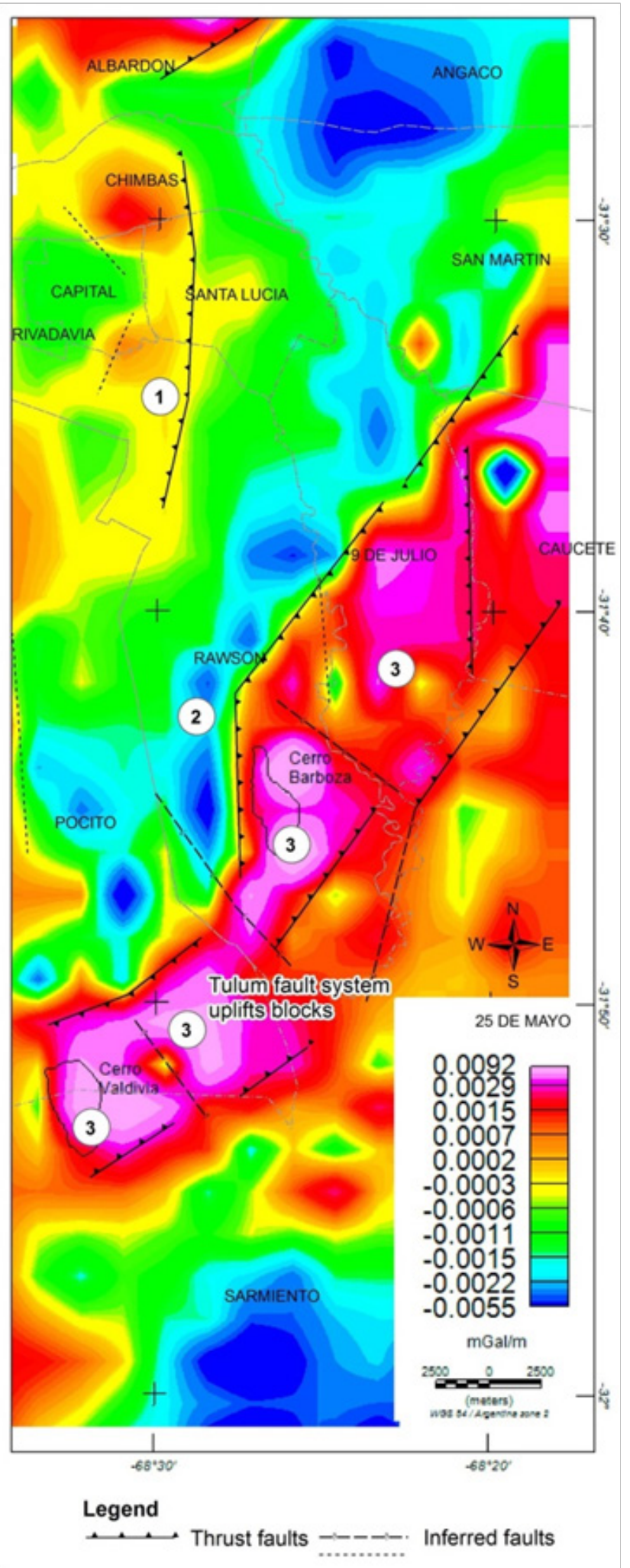

Figure 2 Map of first order vertical derivative. I is a high anomaly, 2 is a low gravity value. It has an approximately elongated shape extending N-S. Area 3 are high anomalies, there is a significant gradient variation increase in that area, there lies the Tulum fault system. Overlapping of gravimetric anomalies with the political boundaries.

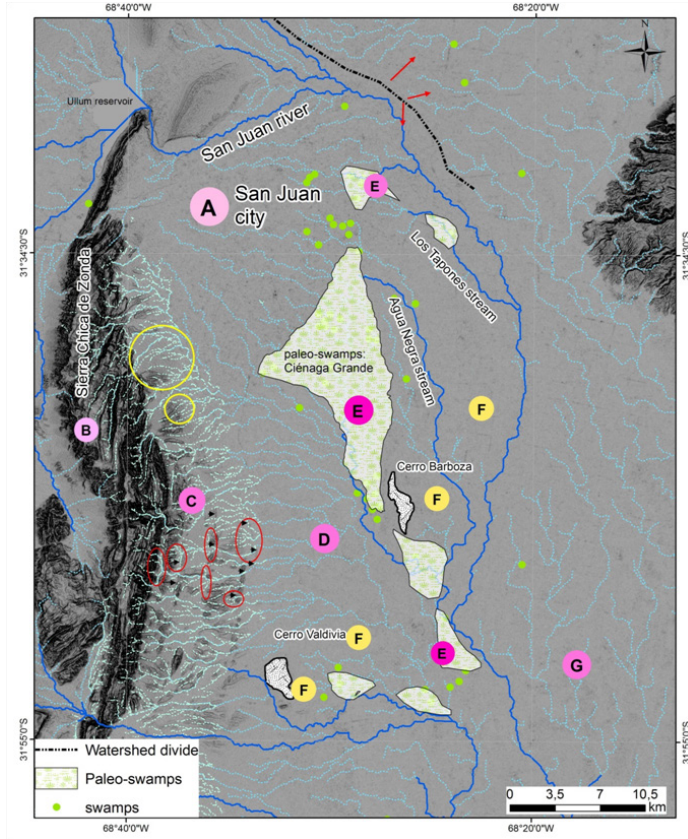

Figure 3 Drainage network of the Tulum valley. The drainage system along the study area can be subdivided into major areas (named A, B, C, D, E, F \& G). See previous text.

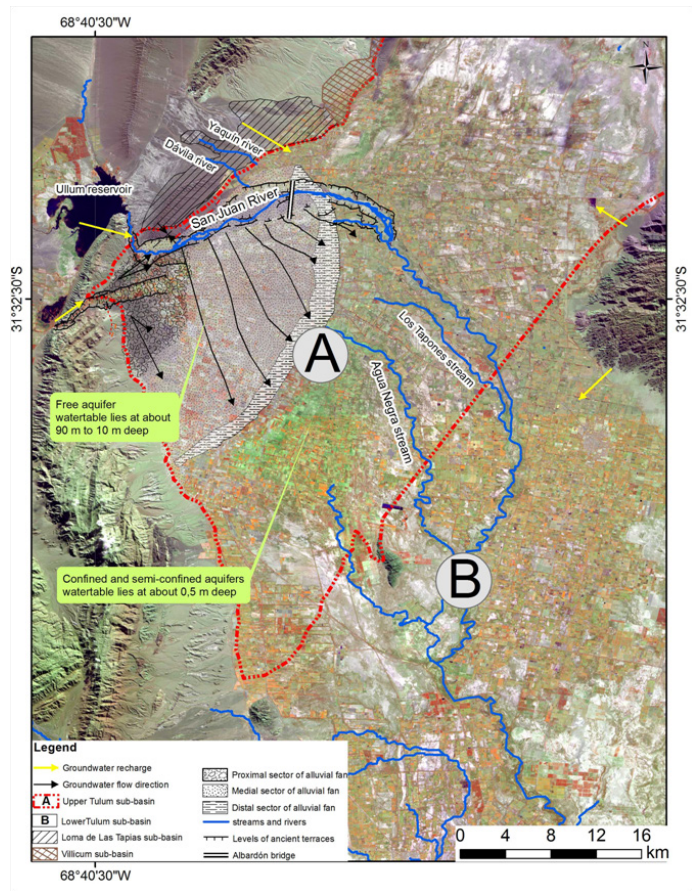

Figure 4 Underground water basin in Tulum Valley and sub-basins.

\section{Discussion}

The Figure 5 shows a map of gravimetric anomalies, faults, distribution of paleo-swamps and wetlands, the drainage network, features related to the groundwater and sub-basin in the Tulum Valley. In addition the limit of groundwater basin (Upper sub basin and Lower Sub-basin). In the area named 1 a gravimetric high was determined by the analysis of gravimetric residual anomalies in the Upper Tulum 
groundwater sub-basin, responding to a Tertiary uplift block within a tectonic context of the modern broken foreland of the Central Andes. Toward the west, this structure promotes an area of greater possibilities for groundwater reserve due to the uplift of the impermeable basement which, most likely, can behave as a barrier to the groundwater flow and, consequently, increasing the chances of finding small depressions holding economically exploitable groundwater resources. In the area named 2, the low gravity values correspond to the basin depocenter. This area receives all the contributions of groundwater and surfacewater. In this area the groundwater table permanently close to the surface and they are considered discharge zones. Here the aquifers are confined and semi-confined. The paleoenvironment associated were the wetlands or swamps (the local term was Ciénagas). The largest body of water had 15000 square kilometers, and was named "Ciénaga Grande" or "Ciénaga Trinidad-Pocito". Also there were small swamps distributed by the basin. The paleo-swamps zone is linked to organics soils in the past wetter environment and the soil types are predominantly clay, clayloam. These soils are poorly drained and have salinity problems. In some places peatland were developed. There, during the summer season underground fires are generated. The area named 3 is the Tulum fault System, corresponds to basement blocks uplifts of a broken foreland basin system. The zone of basement uplifts behaves as a hydrogeological barrier. The central fault split the large groundwater basin located under the Tulum Valley in two sub-basins Upper and Lower Tulum. The transversal faults with NNW-SSE would be generating discontinuities allowing the water flow between both hydrogeological sub-basins. A fault with NNW-SSE direction to south of Cerro Barboza would have connected the "paleociénaga Grande" with small swamps that cross the blocks uplifts. In 3 there are dune fields located above the high gravimetric anomaly gradients indicated and they correspond to the Barboza and Valdivia basements uplifts. The Tulum Fault System act as a topographic barrier to prevent the current winds from the S-SE to deposit sands covers to the west of the raised blocks. Dune fields do not exist to the west of this high in the downthrown block. The sand layer thickness varies from a few centimetres to ten meters. This information is important when planning water drilling for the population.

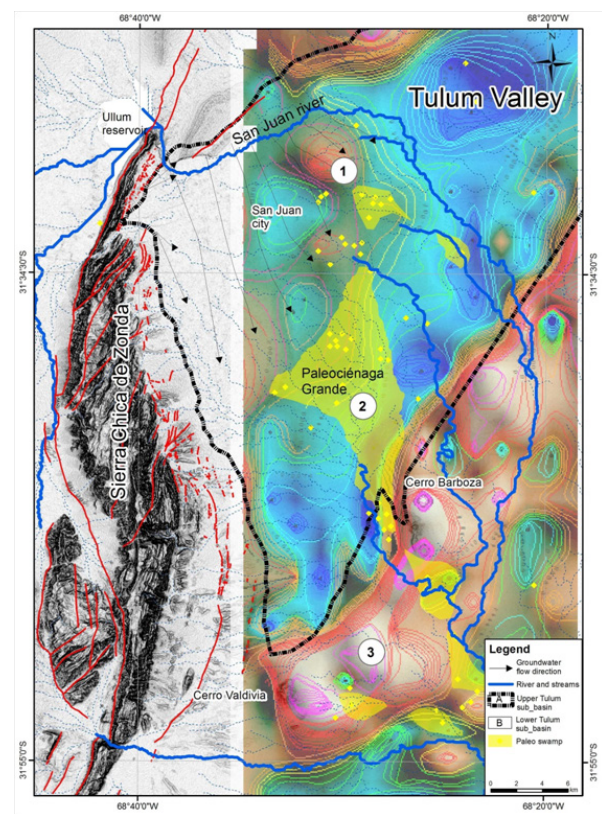

Figure 5 It shows a map of gravimetric anomalies, faults, distribution of paleoswamps and wetlands.

\section{Conclusion}

The drainage network and groundwater are influenced by varied tectonic structures in the Tulum valley. In the piedmont of the Sierra Chica de Zonda broom-shaped river pattern correspond to Quaternary faults. While in the central Tulum Valley, the depocenter is a water recipient. The groundwater table permanently close to the surface and they are considered discharge zones. In the Tulum fault systems streams adapt its drainage network bordering basements blocks uplifts. In turn, the blocks uplift behaves as a hydrogeological barrier for the groundwater basin. Also, in the alluvial fan of San Juan River the free aquifer is affected by a Tertiary uplift block. From this study, it was concluded that tectonic structures in the Tulum Valley control surface and groundwater resources. Consequently, the effects of the tectonic structures are important for new explorations of water available to humans.

\section{Acknowledgements}

Authors would like to acknowledge for supporting this research to: Technological and Social development Project (PDTS) Exploration of Geothermal resources in San Juan. CICITCA-SECITI. (Código E1021); and the Oriented research Project (PIO) Geofísica aplicada a la zonación de los recursos geotérmicos (San Juan) CONICETSECITI N ${ }^{\circ} 150-201501-00039-C O$.

\section{Conflict of interest}

Authors declare there is no conflict of interest in publishing the article.

\section{References}

1. Ortiz A, Zambrano J. La provincia geológica Precordillera Oriental. $8^{\circ}$ Congreso Geológico Argentino. 1981;3:59-74.

2. Jordan T, Isacks B, Allmendinger R, et al. Andean tectonics related to geometry of subducted Nazca plate. Geological Society of America Bulletin. 1983b;94(3):341-361.

3. Jordan T, Allmendinger R. The Sierras Pampeanas of Argentina: a modern analogue of Rocky Mountain foreland deformation. American Journal of Science. 1986;286(10):737-764.

4. Smalley J, Pujol J, Regnier M, et al. Basement seismicity beneath the Andean Precordillera thinskinned thrust belt and implications for crustal and lithospheric behavior. Tectonics. 1993;12(1):63-76.

5. Ramos V, Cristallini E, Perez D. The Pampean flat-slab of the central Andes. Journal of South American Earth Sciences. 2002;15:59-78.

6. Ramos V, Folguera A. Andean flat-slab subduction through time. Geological Society of London. Special Publications. 2009;327(1):31-54.

7. INDEC Estadísticas y Censos. En línea. Ciudad Autónoma de Buenos Aires, Argentina; 2010.

8. Rocca J. Geología de los valles de Tulum Ullum y Zonda. Consejo Federal de inversiones, Argentina; 1970. p. 1-180.

9. Suvires G, Pereyra B, Zambrano J, et al. Rasgos geomorfológicos regionales de la provincia de San Juan. Síntesis del Cuaternario de la provincia de San Juan. USA; 2000. p. 1-35.

10. Perucca L, Vargas N. Neotectónica de la provincia de San Juan, centrooeste de Argentina. Boletín de la Sociedad Geológica Mexicana. 2014;66(2):291-304.

11. Zambrano J, Suvires G. Actualización en el límite entre Sierras Pampeanas Occidentales y Precordillera Oriental, en la provincia de San Juan. Revista de la Asociación Geológica Argentina. 2008;63(1):110-116. 
12. Rodríguez A, Suvires G, Martinez P. Análisis del sector sur del sistema de fallamiento Tulum mediante el uso del método gravimétrico orientado al ordenamiento territorial. Acta Geológica Lilloana: III Jornadas de Geología de Precordillera. 2016a;28:170-177.

13. ARF DAAS. ALOSPALSAR radiometric Terrain Corrected low res includes material@ JAXA/METI 2007. Alaska Satellite Facility. USA; 2016.

14. En línea. Instituto Geográfico Nacional IGN. 2017.

15. Suvires GM. The paradigm of paraglacial megafans of the San Juan river basin, Central Andes, Argentina. Journal of South American. Earth Sciences. 2014;55:166-172.

16. Rodríguez A, Christiansen R, Suvires G, et al. Structural features of the Southern Tulum Fault System, western central Argentina, through gravimetric data and geomorphologic analyses. Journal of South American Earth Science. 2016b;72:159-168.
17. Agie J. Almacenamiento de agua subterránea en las cuencas de Tulum y Ullum-Zonda. Consejo Federal de inversiones, Argentina; 1968. p. 1-26.

18. Jouk1 M. Estudio geoquímico del agua subterránea en el valle de Tulum. Consejo Federal de inversiones, Argentina; 1970. p. 1-77.

19. Lohn P. Hidrogeoquímica en los valles de Tulum y Ullum-Zonda, provincia de San Juan. Estudio de la salinidad del agua subterránea y superficial. Consejo Federal de inversiones, Argentina; 1970. p. 1-70.

20. Lloret G, Suvires G. Groundwater basin of the Tulum Valley, San Juan, Argentina: A morphohydrogeologic analysis of its central sector. Journal of South American Earth Sciences. 2006;21(3):267-275.

21. Zambrano J. El límite oriental de la Precordillera en el Valle de Tulum. Actas de las $1^{\circ}$ Jornadas sobre Geología de Precordillera, Argentina; 1986. p. 349-353. 